\title{
Systemic Approach in the Study of Problems of Territories's Sustainable Ecological and Economic Development
}

\author{
Gubaidullina T.N. \\ Kazan Federal University, Institute of Management, Economics and Finance, Kazan, 420008, Russia \\ Email: m155308@yandex.ru
}

\section{Doi:10.5901/mjss.2015.v6n1s3p232}

\begin{abstract}
The article analyzes the problems of sustainable development of ecologic and economic system. Based on the system approach methodology categories reflecting the essential characteristics and evolution of the regional eco-economic system, the general characteristics of its sustainability are investigated. Factors for sustainable ecological and economic development of the territories are identified.
\end{abstract}

Keywords: Sustainable development, ecologic and economic system, region, systemic approach, life support, value appraisal of natural resource potential, ownership relationships of natural resources.

\section{Introduction}

The scientific knowledge methodology uses various theoretical approaches which help to study the processes and phenomena of objective reality. A systemic approach should be considered as one of the conventional methods of dialectical knowledge laws of society and nature development; it enables to scientifically analyze various systems in their interrelationship and interdependence.

The systemic approach is based on the dialectics of the objective and subjective, the unity of theoretical research and practical experience upon which we study a real system, its cognition and reflection take place in the human mind, and then system knowledge received influences practically the system, the conscious control of its functioning and development. Dialectical and comprehensive research based on systemic approach is the most effective scientific methods of research as opposed to mechanistic linear-causal way of thinking. Systemic approach is a qualitatively higher method compared to the narrow objective method of scientific knowledge, as it is based on knowledge from the individual to the general, from the abstract to the specific, from the unambiguous to many meanings, from one-dimensional to the multidimensional, etc.

Today's prominent foreign scientists involved in research of economy and natural systems, namely J. Forrester ("World Dynamics", 1971), Donella H. Meadows, Dennis H. Meadows, J. Randers, R. W. Behrens (" The Limits to Growth", 1972), E. Pestel ("Beyond the limits to growth ", 1987) and others, based their work on ideas of system dynamics that led to a number of serious theoretical conclusions and practical design of feasible models of the dynamics interaction of natural and economic processes, which are widely used in the practice of economic analysis in the developed world and in major international organizations when preparing summaries and forecasts for future development. At the same time it should be noted that integral systems are not the only form of objects existence of reality, and systemic approach in this regard is not the only form of society and nature cognition.

\section{Theory}

Ecological and economic system should be developed and improved preserving its integrity and ensuring the dynamic balance of all its elements. The negative environmental consequences of human activities are the result of increasing anthropogenic disruption of the dynamic balance of natural systems, which means decrease of stability and growing danger of its degradation.

The stability of the system in the general sense should be understood as preservation of its properties, the qualitative and quantitative characteristics of the elements and relationships under the negative destabilizing influence of the external environment. In other words, the system is stable, if under adverse external conditions, it is able to perform its functions at the appropriate level, to dynamically grow and develop. 
Sustainable ecological and economic system is, above all, the ability of the economy to function normally in the ecological crisis, and the ability of the ecological system to maintain its properties and to perform the necessary functions in economic instability. Ecological and economic system is considered stable if, on the one hand, the economy is elastic with respect to the environmental crisis situation (under negative impacts of floods, droughts and other natural disasters), and on the other hand, the nature withstands high pressure associated with economic growth and its consequences.

Developing systems are characterized, on the one hand, by stability of the structure, and on the other, by the loss of stability, degradation under the influence of certain factors of the same structure and creating another new high-quality, stable structure. Here we see a real manifestation of the law of transition from quantitative to qualitative changes. The development process can be represented as a sequence of evolutionary cycles of change within one cycle with an abrupt state transition at the end of the cycle to a new level, which means the beginning of a qualitatively new cycle of the regional system development.

The consequence of cyclical development is irreversible process, i.e. it is impossible to transit from new to the old structure, which was already destroyed. Too stable system is incapable of development, since it suppresses any deviation from its hyperstability state. To go to a new quality, a system must be unstable at some point. However, the constant instability is also harmful for the development of the system as well as hyperstability, as it excludes consolidation of useful features in the regional system. Evolution of ecological-economic system is a constant dynamics of stability instability state, due to the cyclical development of ecological and economic relations and the manifestation of the ecological and economic crises at different stages of social development.

\section{Results}

Sustainable regional ecological-economic system should be understood as the maintenance of life support based on the valuation of natural resource potential, the effective application of investment and innovation policies for environment management, the management of macroeconomic accounting of the nature's potential use for economic purposes, the development of all environmental businesses by organizing environmentally friendly production to create environmentally friendly products.

As a part of the ecological-economic system, stability and balance can be through the establishment of an effective economic mechanism to regulate the environmental sphere, taking into account the laws of natural systems and the objective economic laws in order to achieve optimal solutions of twofold task: improving the welfare of humanity, while maintaining an optimum state surrounding habitat.

Sustainable ecological and economic system of the territory is characterized by properties of self-organization, selfsufficiency, self-preservation. Under the self-sufficiency in the general theoretical sense one should be understand the best match between the substantial and attribute characteristics, between the form and content of the functioning and developing eco-economic system and its individual elements. The processes of self-organization are characterized by the space -structural aspect of the study of the regional eco-economic system, the relationship hierarchy of its components, allowing to reach balanced, sustainable ratio of environmental and economic interests of eco-economic system in the modern conditions of instability, cyclicality, public relations crisis development. In this context, the problem of components self-preservation of the ecological system in a deep systemic crisis, and accordingly, the preservation of economic processes, entities and characteristics of their development in the context of deepening ecological instability is very important.

To ensure the preservation of functional, structural and integrative properties of the ecological-economic system, the stability of its structure is of particular importance. The stable structures of the regional eco-economic system should be understood as its ability to withstand the constantly occurring changes in natural and economic components, which allow you to keep these changes within the required quality. The presence of stable relations guarantees the integrity of eco-economic system within specified quantitative and qualitative parameters in a specific temporal and spatial aspect of ecological-economic interaction.

In this regard, the concept of sustainable, dynamic balance is discussed quite rightly in the economic literature, it is characterized by a certain qualitative state of the ecological-economic system associated with a fairly long time balance when the internal elements of the economic and ecological systems can withstand the negative impact from the outside and do not violate, but maintain its functional properties.

The society which is balanced is able to respond to changing internal and external conditions establishing new balance corresponding to these changes, both within itself and within the whole environment of its habitat [1, p. 144-145]. In this respect, the main task of the present social progress is, in our opinion, to establish the necessary ratio between the development level and the quality of economic and ecological relationships in the region to ensure a proper quality of life 
in all its diverse manifestations and characteristics.

Eduard Pestel, a prominent German scholar and public figure, a specialist in the field of automatic control theory and systems analysis was the most accurate in reflecting reality in the scientific analysis of the impact of economic growth on the environment. In his book "Beyond the limits to growth", prepared as a report for the Club of Rome, the author analyzes the global challenges of world development, and puts forward the theory of "organic development", in which he offers his own answer to the question: which option is preferable for human development - further growth, accompanied by a further depletion of resources and, finally, by complete degradation of ecology and resources, or zero growth, with all its negative consequences that inevitably will be expressed in endless internal and external conflicts that arise when distributing national wealth and, ultimately, in complete chaos [2, p. 83].

The theory of "organic development" is relevant primarily because it basically contains the provisions of the following kind: "For the welfare of people what has no money value - clean air, fresh water - is much more important. The current level of pollution is mostly the result of the negative effects that have been accumulated from previous years, when no one cared about restricting them somehow. So the future will be forced to pay for the present, if we, through ignorance, carelessness or impatience to get more benefits will force future generations to suffer from pollution caused by us and bear the costs of its cleanup" [2, p. 87-88].

System principles used in the theory of "organic growth", namely systemic and interdependent development of all elements of the system, allowing them to grow without prejudice to each other; harmonious coordination of the development goals when new goals to meet the needs of the time, are set at least after reaching the old ones; flexible development of systems associated with their ability to go their own way regardless of the adverse effects of factors that do not affect the vital functions of the system. These principles allow to scientifically conduct multivariate analysis, and therefore they should be used to work out national models of ecological-economic development of the territories.

Model of sustainable ecological and economic development of the territory can be represented as an aggregate of economic, environmental, institutional innovations, and social factors.

$D t=f(E, C, I, M, S)$,

where

E - economic factors,

C - environmental factors,

I - institutional factors

$M$ - innovative factors

$S$ - social factors.

Economic factors play fundamental role in this system; they may be represented by a function of financial, tax and investment components.

$E t=f(F, H, J)$,

where

F- financial factors,

$\mathrm{H}$ - tax factors

$\mathrm{J}$ - investment factors.

Institutional research approach involves scientific analysis of institutions ensuring sustainable ecological and economic development (Fig. 1).

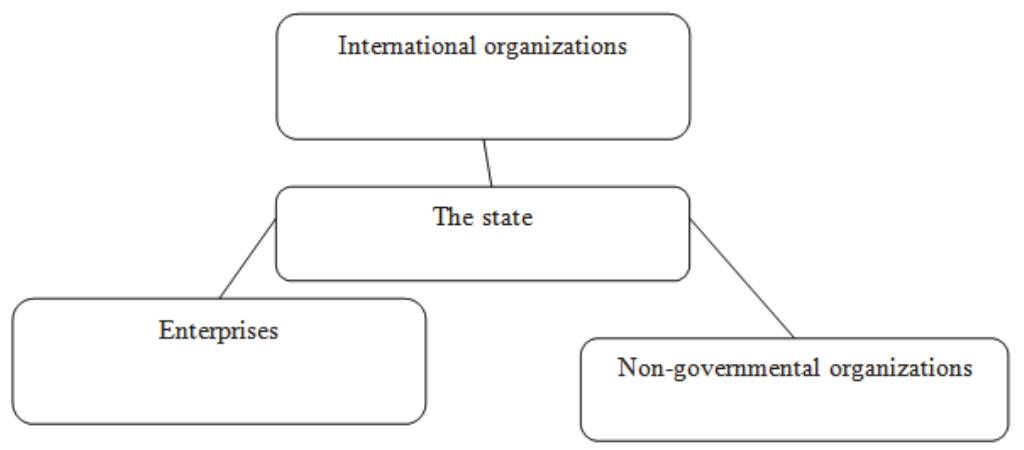

Fig.1. System of institutions in ecological and economic relations 
The system of ecological and economic relations is characterized by interconnected and interdependent functions (Fig. 2).

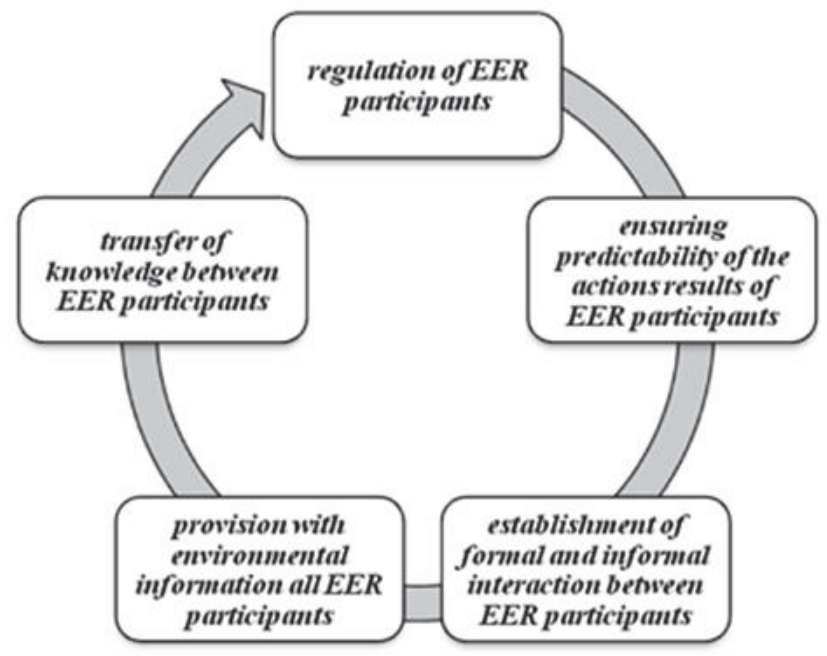

Fig.2. The functions of the institutional system of environmental and economic relations.

According to the Russian practice of forming the institutional mechanism of regulating ecological and economic relations one should highlight the following regulations (Table. 1).

Table 1. Laws regulating ecological and economic relations in the Russian Federation [3, p.424-425]

\begin{tabular}{|c|c|}
\hline Laws & Sphere of regulation \\
\hline $\begin{array}{l}\text { "On Amendments to the Federal Law" "On the } \\
\text { continental shelf of the Russian Federation" dated } \\
\text { 30.12.2012 №287-FZ }\end{array}$ & $\begin{array}{l}\text { improvement of legal regulation in the case of negative impact on } \\
\text { the marine environment with oil spills }\end{array}$ \\
\hline $\begin{array}{l}\text { "On amendments to Administrative Offense Code of } \\
\text { the Russian Federation" }\end{array}$ & $\begin{array}{l}\text { differentiation of administrative offenses in the field of waste } \\
\text { production and consumption. }\end{array}$ \\
\hline $\begin{array}{l}\text { "On amendments to some legislative acts of the } \\
\text { Russian Federation" }\end{array}$ & $\begin{array}{l}\text { upgrading penalties for production, circulation, including storage, } \\
\text { transportation and sale of tigers, leopards and other rare and } \\
\text { endangered species of animals listed in the Red Book of the } \\
\text { Russian Federation, or protected by international treaties }\end{array}$ \\
\hline $\begin{array}{l}\text { Russian Federation Government Resolution "On } \\
\text { Approval of the calculation rules of damage caused } \\
\text { to mineral wealth due to violation of the subsoil } \\
\text { legislation of the Russian Federation" }\end{array}$ & procedure for calculating damage as a result of selective mining. \\
\hline $\begin{array}{l}\text { Russian Federation Government Resolution of } \\
\text { 11.10.2012 №1039 }\end{array}$ & $\begin{array}{l}\text { amendments to certain acts of the Government of the Russian } \\
\text { Federation on the provision of water bodies in the use and } \\
\text { maintenance of the State Water Register }\end{array}$ \\
\hline
\end{tabular}

\section{Conclusions}

Conceptual framework of sustainable ecological and economic development over time is filled with new content, expanding range of issues to be solved in the process of its implementation $[4,5,6,7]$. Thus, the final documents of Rio+ 20 summit reaffirmed the need for sustainable development by promoting sustained, inclusive and equal economic growth, creating more opportunities for all, reducing inequalities, improving basic living standards, promoting equal social development and integration, promoting integrated and sustainable management of natural resources and ecosystems that are consistent in particular with the objectives of economic, social and human development and at the same time contribute to the conservation of ecosystems and their regeneration and recovery and increase their resistance in the face of new and future challenges [8]. It was noted that with the participation of scientists on the basis of long-term forecasting system it is necessary to justify the global goals of sustainable development till 2030 
To achieve the goals of sustainable ecological and economic development it is necessary to change priorities of socio-economic development of the region, putting a human being at the center of all economic and environmental problems, given, first of all, not only quantitative criteria for his/her well-being, but also the quality parameters of the standard of living, quality of life, life expectancy, preventing the negative impact of environmental factors on the health of present and future generations as an important factor in the reproduction of the labor force in the regional system.

\section{References}

Zhirnova G., Absalyamova S. Global innovation gap and quality of education// 16th International Conference on Interactive Collaborative Learning \& 42nd IGIP International Conference on Engineering Pedagogy, Kazan, Russia, 2013.

Pestel, E. Beyond limits to growth / Eduard Pestel. - M .: Progress, 1988.

State Report "On the State and Environmental Protection of the Russian Federation in 2012". - M.: Ministry for nature management, 2013.

Urazmetov, I.A., Smirnova, E.V., Kadyrova, R.G. Features of the soil of subboreal semihumid landscape zone within urbanized areas. Mediterranean Journal of Social Sciences, 5 (18 SPEC. ISSUE), pp. 373-377

Gubaidullina TN, Kundakchyan RM, Tufetulov AM Methodological approaches the study of sustainable ecological and economic development of regional systems / TN Gubaidullina, RM Kundakchyan, AM Tufetulov // Kazan economics. - 2013. - №2. - P. 102105.

Gubaidullina TN Comparative analysis of environmental-economic status of the Russian regions / Sh Valitov T.N.Gubaydullina, El Baybakov El, RM Kundakchyan, AM Tufetulov // Kazan economics. - 2014. - №2.

Grigorieva EA Gubaidullina TN Financial and ecological and economic sustainability of economic agents: issues of research methodology / EA Grigorieva, TN Gubaidullina // Intelligence, innovation, investment - 2012. - № 3. - pp 98-100.

Gubaidullina TN, Kalmikova A.A.Investitsionnoe sustainable ecological and economic development of modern society / TN Gubaidullina, AA Kalmikova // Kazan science. - 2012. - № 11. - pp 80-83.

Denmukhametov, R.R., Zjablova, O.V. Geodemographic situation in the Republic of Tatarstan. World Applied Sciences Journal, 30 (11), pp. 1684-1688

Smirnova, E.V., Urazmetov, I.A. (2014). Specifics of land cover of natural anthropogenic landscapes in oil production regions. International Multidisciplinary Scientific GeoConference Surveying Geology and Mining Ecology Management, SGEM, 1, pp. 765770.

The Resolution adopted by the UN General Assembly 66/228 of 27 July 2012 - Electronic resource - Mode of access: http://daccessdds-ny.un.org/doc/UNDOC/GEN/N11/476/12/ PDF / N1147612.pdf? OpenElement

Maslov, D.G. On the problems of improving the dialectical method of study of socio-ecological-economic systems / D.G. Maslov // News of higher educational institutions. Volga region. Social sciences. Issue 4 (16). - 2010. - p. 168-176.

Komarova, V.N., Zjablova, O.V., Denmukhametov, R.R. An infrastructure factor in regional competitiveness. Mediterranean Journal of Social Sciences, 5 (18 SPEC. ISSUE), pp. 355-360.

Urazmetov, I.A., Smirnova, E.V. (2014). Ecological state of water and soil of natural-anthropogenic landscapes in the oil-producing regions. Mediterranean Journal of Social Sciences, 5 (18 SPEC. ISSUE), pp. 367-372. 